International Journal of Engineering \& Technology, 7 [2.29] [2018] 675-681
International Journal of Engineering \& Technology
SPC
Website: www.sciencepubco.com/index.php/IJET
Research paper

\title{
Uses if Social Media as Electronically Mediated Interpersonal Communication [EMIC] on Commuter Marriage Family [Phenomenology Studies at Postgraduate Women Student in Abroad]
}

\author{
Yuanita Setyastuti ${ }^{1 *}$, Jenny Ratna Suminar ${ }^{2}$, Purwanti Hadisiwi ${ }^{3}$, Feliza Zubair ${ }^{4}$ \\ ${ }^{1}$ Padjajaran University and Lecturer of 1 Lambung Mangkurat University \\ ${ }^{2}$ Padjajaran University and Lecturer of 1 Lambung Mangkurat University \\ ${ }^{3}$ Padjajaran University and Lecturer of 1 Lambung Mangkurat University \\ ${ }^{4}$ Padjajaran University and Lecturer of 1 Lambung Mangkurat University \\ *Corresponding Author E-Mail: Yuanita.Setya@Gmail.Com
}

\begin{abstract}
Self-actualization, career and professional demand sometimes require a person to pursue further studies at a higher level for both men and women. A woman who has married and has children then studying a postgraduate abroad certainly faces a complicated situation relating to eastern and patrilineal cultures that are identical to the roles and responsibilities of mothers in domestic affairs and parenting. In carrying out the role, required high quality communication by media with spouses and children when being separated residence during a relatively long study and with a long distance location. The aim of this study is to know how the uses of social media as electronically mediated interpersonal communication [EMIC] on commuter marriage family at Postgraduate Women Student in aboard. This is a qualitative approach study with phenomenology studies. Study done by depth interview with 4 [four] respondents whose studied at aboard, in Australia, America, and Europe. The result of this study was found that the respondent used Social Media to ccommunicate with their family, especially by WhatsApp, Line, Facebook and Skype. Most of respondents have enough skills of both sender and receiver for electronic message. Most of respondents also have enough communication richness, communication speed and presence. Social media also augment family communication by providing opportunities for social support beyond family members. The respondent also could kept maintaining the role of a mother and reduce the loneliness feeling and guilty feeling by video call and social media chatting. The contribution of this study was to give recommendation to some mother and/or wife who are in commuter marriage to escalate the skills of family communication trough social media so they could still run the role of mother and/or wife as much as they could.
\end{abstract}

Keywords: Electronically Mediated Interpersonal Communication [EMIC]; Commuter Marriage; Family Communication, Parenting

\section{Introduction}

Education is a right, necessity and needs of every people. Selfactualization, career and professional demands sometimes require a person to pursue further studies at a higher level for both men and women. A woman who is married and has children and studying abroad at postgraduate, certainly faces a complicated situation relating to eastern and patrilineal cultures that are identical to the roles and responsibilities of mothers in domestic affairs and parenting. In carrying out the role, required high quality communication by media with spouses and with or without children when being separated residence during a relatively long study and with a long distance location. The high quality of communication always needed especially in eastern culture. Mother is the first and the main "madrasah" for their children. Women and wife in patrilineal culture usually has to stay at home. There were a lot of perception and task when a wife and/or a mother decided to stay in another country to study and live long distance relationship with their family as commuter marriage. As a wife and/or a mother their must to fulfilll their role although their being separate resident during relatively long study and with a long distance location and maybe only go home in vacation. The high quality of communication could be achieved by the right media. Electronically Mediated Interpersonal Communication [EMIC] refers to uses of electronic media to interpersonal communication, to build and maintain relation with spouse, friends, and family. There are 79 million people using social media from the total 88,1 million people whose access internet [www.We are Social, Digital In Indonesia 2016] Social media facilitate communication when family members no longer live together or even in close proximity. Nasrullah stated that social media is medium in internet that make the user possible to representation them self and interaction, cooperation, sharing, and communicating with another user and built a virtual of social belt [1]. The facilities of social media like texting, voice call and video call could facilitate a wife and/or a mother to keep communicate with family member and do her role as wife and or a mother. 


\section{Literature Review}

\section{Literature riview of this studies are :}

\subsection{Family and Family Communication}

Families been defined in biological, legal, or self-defining ways. Families defines as: 1] Through their relatedness by biological, legal, or marriage-like commitment, 2]. Through their functions of nurturing by encouraging physical, social, emotional, and intellectual growth, 3] Trough their control by limiting the behavioral options of family members through their inclusion in the family unit[2].

Family is an intimate group that generate sense of home and group identity, complete with strong emotional bond and loyalty, and historical and future experience [3]. Family has some types, 4 types of family namely: 1] traditional type of families, with two parent and one or more children from the union of parent. 2] Single parent families, with one parent and one or more children. 3]. Blended families, with two adult people and children, some or all of whom may not be from the union of those parent.4] communal and other families.

Olson and McCubbin in [4] ssuggests about 7 [seven] stages of family life cycle, those are:

"Stage 1: Young married couple without children, Stage 2: Families with preschoolers children, Stage 3: Families school age children, Stage 4: Families with adolescents children, Stage 5: Launching family [sending young adults into the world], Stage 6: The empty nest families [life after the children], Stage 7: Retirement years Families"

Historically, marriage has been regarded as a means to other goals. In hunting and gathering societies, unions were strategic arrangements to preserve peace between tribes. Study found that Americans have viewed raising children as a primary objective of marriage [Coontz in [5]. But nowadays, raising children is no longer seen as the only goal of marriage, because in $1990,65 \%$ of Americans said children were very important to successful marriage, but two decades later only $41 \%$ believe that things . Nowadays most people objective of marriage are individualized relationships, which enhance each partner's personal accomplishments and satisfaction[5]

Family Communication defined by [2] as messages that are typically sent with intent, messages that are typically perceived as intentional. The messages in family communication has consensually shared meaning among individuals who are related biologically, legally, or through marriage like commitments and who nurture and control each other. Verderber and friends stated about the importance of family communication, which is it serves at least three major purposes for family member individual [3] :

a.

Family communication contributes to the self-concept formation of family member

b. $\quad$ Family communication supplies needed of recognition and support

c. Family communication establishes models of communication behavior.

Much of the functioning of family system is a product of communication within the family.

Fitzpatrick and Best, Kener, Noller in [5] identified three distinct types of relationships in couple and family:

a) Traditional. Couples who fit into the traditional category are highly interdependent and emotionally expressive with each other, share conventional views of marriage and family life, and engage in conflict regularly.

b) Independent. Independents hold less conventional views of marriage and family life. Compared to traditional, independents are less interdependent, more emotionally expressive, and they engage in conflict more often. Autonomy is moderately high for independents, so this couple type is likely to have fewer common interests and activities than traditional couples. Nowadays there a far greater number of independ- ents because greater emphasis is now placed on individual fulfillment and personal happiness.

c) Separates. Are highly autonomous. Partners give each other plenty of room, and they share less emotionally than the other two types. Separates also try to avoid conflict, perhaps because it often involves emotional expressiveness and pushes them to negotiate to reach a common decision rather than to operate separately.

d) Not all of the couple fit in one of three of those types, so the couple could place in "mixed marriages which is the husband and wife subscribe to different perspectives on marriage. The most common form of mixed marriage is the separate-traditional couple. Notarius in [5] identifies three key elements that influence satisfaction with long-term relationships:

e) Words refer to how family members talk and behave toward each other in the family. Communication influences selfesteem and feelings about the relationship. In happier relationships, members tend to communicate more support, agreement, understanding, and interest than in less happy couples. Unhappy families include frequent criticism, negative statements, mind reading, and egocentric communication.

f) Thoughts, refers to how family members think about each other and family. Because the thoughts shape the emotions and words. In satisfying relationships, people tend to attribute nice actions by others to stable, internal qualities that are within individual.

g) Emotions. Are affected by words and thoughts. How we feel is affected by what we say to others and what we communicate to ourselves through self-talk.

h) Chapman in [5] has identified five distinct ways that we communicate love, which calls the five love languages:

i) Affirming words: Written or oral compliments support, and expressions of valuing another communicate love.

j) Quality time: Being mindfully present with another and giving another your total attention for an extended amount of time are loving behaviors.

k) Gifts: Gifts are tokens of affection and thoughtfulness.

1) Service: Doing chores or unrequested favors such as tuning up a car tells another that you care about her or him.

m) Touch: Physical contact, sexual or otherwise, is an important way of expressing affection and intimacy.

The family communication literature shows that there is a definite link between how you think and how you communicate within families. In other words, cognition and communication are linked in fundamental and important ways. Its regarding to cognition, perceptions, attributions, and expectations provide the frame of reference within which communication episodes within the family occur. Powerful research showing that regardless of the facts, if people perceive their family member positively, they will be more satisfied in that relationship and the relationship will be more stable Conversely. On the other side, if people see their family member negatively, they will be less satisfied and their relationship is likely to be less stable.

\subsection{Parenting and Family Communication}

Parental is ideally shared by mothers and fathers, because each of them has their own roles for their children. The bond between father and son will give its own color in the formation of a child's character. If in general the mother portrayed a figure that provides protection and regularity, while the father helps children explore and love the challenge. If the child is taken care of by both optimally, it will form a sense of security and trust in the child [6].

Trenholm and Jensen [4] mentions that one of the competencies in family communication is the competence in determining the role, where a mother of course must be able to put themselves in accordance with the role and fulfill the expected demands. So that, mothers interaction with children is necessary. Lestari revealed that one of the functions of the family is the socialization function 
to prepare the child to be a good member of society [7] . Mothers must communicate effectively in building relationships with children. Messages support from parents such as praise, acceptance, courage, and affectionate appeals are associated with high selfesteem in children and compliance with the greater authority [4].

Parenting, especially children in toddler and preschool ages, require more attention and energy because they still very depend on their parent. Edwards and Liu in [8] mentions that experts on toddlers are increasingly concerned to recognize the unique characteristics of toddlers and problems that require attention to parenting and parenting guidelines for interacting with toddlers. On commuter marriage family, there are need egalitarian view and gender equality, especially when the wife must go aboard to work or school. According to [9], couples with equally egalitarian gender role attitudes are the most psychologically prosperous couples, while the two have traditional psychological wellbeing among the other groups. Stress or pressure among husband or wife mcan caused by inbalanced manner of sharing affairs of the house, especially in women who will reduce harmony in marriage life [10].

\subsection{Commuter Marriage}

Gerstel and Gross in [11] described commuter marriage as "men and women in dual-career marriages who desire to stay married, but also voluntarily choose to pursue careers to which they feel a strong commitment and establish separate homes . Commuter Marriage defined as spending at least three or four nights a week away from the primary family residence and maintaining a second residence in another location [e.g., Gretel \& Gross, 1984; Rhodes, 2002; Stafford, 2005; Winfield, 1985 in [11] The commuter marriage has two criteria : first, both spouses must have residences in separate geographic locations and second, to accommodate the careers of both spouses is especially as the reason for establishing separate residences [Rhodes in [11]

Sahlstein, 2006; Stafford, 2005 in [5] stated that a majority of college students are have been in long-distance romances. Then, he stated that there are three problems, or tensions, are commonly experienced in long-distance relationships are : the lack of daily sharing of small event, unrealistic expectation for time together, and unequal effort invested by the two partners. Each proplem can be addressed with communication,. [5].

a. The lack of daily sharing of small event ; sharing ordinary comings and goings helps partners keep their lives in rewoven. Routine conversations form and continually reform the basic fabric of our relationships [Wood \& Duck in [5] 329]. But nowadays, technology allows us to engage in more sharing of everyday things life, even if not via face-toface conversation.

b. Uunrealistic expectation for time together; the lack of routine contact leads to unrealistic expectations for time together. Partners have limited time together; they often think and hope that every moment must be perfect in quality and quantity. But sometimes it not always happens, although they may be even more likely in reunion of long distance couple because partners used to living alone and have established independent rhythms

c. Uequal effort invested by the two partners; Not equally investment could built dejection to person whose assuming majority of work to keep relationship alive and may create guilty feeling to the person whose investing less. [5]

However, those problems not always disturb the long distance relationship, especially if they could maintain the good quality of communication. Many people maintain satisfying commitments despite geographic separation. In fact, there are some noteworthy advantages of long distance relationships. Blake, Reske \& Stafford, in [5] stated that the couples whose are not together continually could tend to be more passionate and more loving each others when they are together. Then, he said that commitment, flexibility, and effective interpersonal communication could help the couples meet the challenges of keeping romance healthy and satisfying over the life of the relationship. [12] studies found indicate that the dialectics play a role in the relationship satisfaction, communication satisfaction, and feelings of understanding of long distance married couples. Furthermore, a potentially important communication-related variable at work in long distance marriages indicated by the feelings of understanding or misunderstanding scale performed well both as a predictor and outcome variable. Finally, sustenance strategies at work in long distance marriages are significantly related to dialectics and feelings of understanding or misunderstanding [12]

\subsection{Electronically Mediated Interpersonal Relationship [EMIC] and Social Media}

Electronically mediated interpersonal communication includes interactions both online and offline. Offline types are by orally via cellular telephone, online types are by email, newsgroup, and chat room. [3]. The most online communicating is written, then people are able to show verbal skills and humor in the writing, therefore Electronically Mediated Interpersonal Relationship has some advantage for interpersonal relationship. The user of writteng message can focus on words and don't have to deal with physical attributes, which is often dominate early preferences for relation partner in face to face setting. So people found that they have no difficulty meeting and developing relationship in this medium.

Furthermore, Boneva, Jenings and Wartela in [13] stated that other research indicates that women spend more time using email than men and women believe that the Internet is useful for keeping up with family and friends more than men.

Two skill of online Message in Electronically Mediated Interpersonal Communication by [3] are : 1]. Sender skill are use concrete word, provide detail, describe feeling, present idea politely; 2]. Receives skill are listen actively, sensitive of another feeling, paraphrase idea before respond, supportive, praise and comforting others.

The choices for improving online communication skills [14] are :

a. Improving sender skill for electronic message by is succinct when necessary, write literally, stay polite, and take a deep breath.

b. Improving receiving skills for electronic message by check in with sender, show empathy when possible, listen beyond the words.

c. Improving sender and receiver skills for electronic messages by take responsibility for your own words, built your dialogue and recall the challenge of online communication AARP and Microsoft conducted a joint research project to examine how computers, mobile devices, and the Internet affect frequency and quality of communication among family members. The results are $83 \%$, including at least $80 \%$ in every age group, regards online communication as a helpful way to stay in touch with family members. More than two-thirds of teenagers think computer contact increases both the quantity and quality of their communication with family members who live a substantial distance from them. Only slightly fewer people aged 39 and older think computer contact increases the frequency [63\%] and quality [57\%] of contact with family members [5] .

Social media facilitate communication when family members no longer live together or even in close proximity. [1] stated that social media is medium in internet that make the user possible to representation them self and interaction, cooperation, sharing, and communicating with another user and built a virtual of social belt. Three categorize of social media: social networking, blog, microblogging, media sharing, social bookmarking, and wiki. The most popular social media is social networking such as Facebook [1] . Parents and children can video chat when children are engaged in study abroad programs or when they move a significant distance from their parents' home. Social media also augment family communication by providing opportunities for social support beyond family members and face-to-face friends. Many people belong to online communities that provide social stimulation, advice, and support [5]. 
Social media have changed family communication many ways. One obvious change is that social media increase the ways that family members can interact. Smart phones allow contact between young children and parents, between parents, among siblings, and so forth. As children grow older and need more independence from family, social media have complex influences. On the one hand, social media make it very easy for adolescents to stay in minute-by-minute contact with peers and, thus, to establish relationships outside of the family. Yet those same media make it easy for adolescents to stay in touch with parents. Some teenagers text their mothers 15 times a day, asking their moms' opinions. That makes it harder for adolescents to achieve a healthy degree of separation from parents [Hafner, 2009; Turkle, 2008 in [5].

Problem Statement: "How the uses of social media as electronically mediated interpersonal communication [EMIC] and the skill as sender and receiver in online communication on commuter marriage family at Doctoral Women Student in aboard?"

Objection of Studies : The aimed of this study was to know the uses of social media as electronically mediated interpersonal communication [EMIC] and the skill as sender and receiver in online communication on commuter marriage family at Doctoral Women Student in Aboard.

\section{Methodology}

The method of this study was qualitative approach with phenomenology studies. Data collected by depth interview with interview guideline. The respondent of this study was 4 [four] women whose studied postgraduate program at aboard, in Australia, America, and Europe. The criteria of respondent were: women whose studied postgraduate program at aboard, married women with or without children, living a commuter married and stay in separate country with family more than 2 weeks.

\section{Results and Findings}

\subsection{Results}

Based on interview with 4 [fours] respondent, the result of these studies was found some finding research:

\subsubsection{The Uses of Social Media to communicate with thee family.}

Based on interview with 4 [fours] respondent, the result of this studies were found that the respondent communicate with their family by texting or chat message, voice call and video call through social media use WhatsApp., Line, Skype, BBM, Facebook, and Facebook messanger.

a. The applications used by respondents to communicate with family through video calls are illustrated in the following chart diagram:

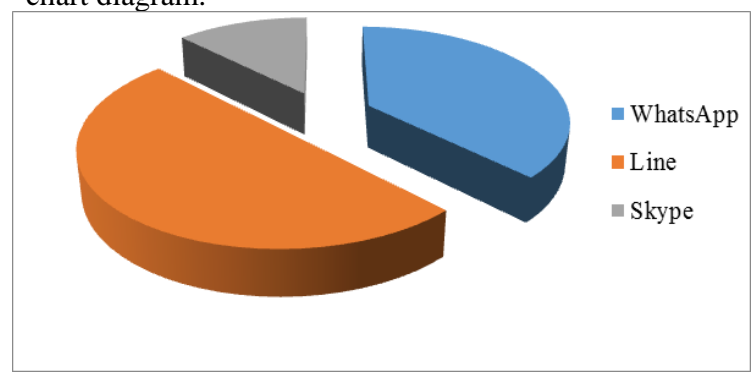

Fig. 2: Video Call

Based on picture 1, respondent use WhatsApp, Line, and Skype application to video calling with their family. The majority respondent use line to communicate by video call with their family.

b. The applications used by respondents to communicate with family through texting message are illustrated in the following chart diagram:

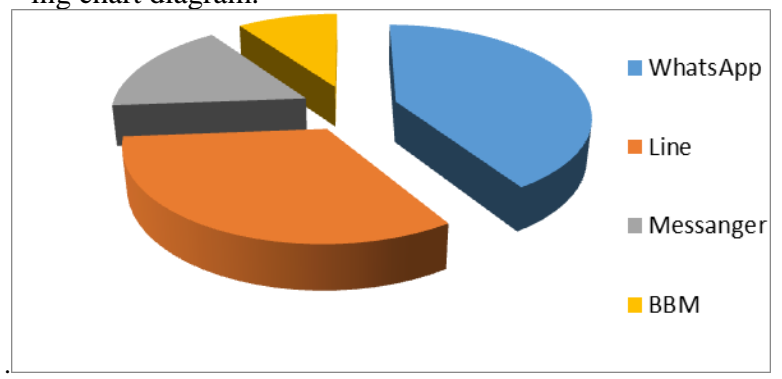

Fig. 2: Message

Based on picture 2, respondent use WhatsApp, Line, messenger and BBM application to texting chat or sending message with their family. The majority respondent use WhatsApp to communicate by text with their family.

\subsubsection{Skill of sender and receiver of electronic Message}

Based on interview with 4 [fours] respondent, the result of this studies were found about respondent skills of sender in electronic message, skills of receiver in electronic message, and skills of sender receiver in electronic message.

Table 1: Skill of sender and receiver of electronic Message

\begin{tabular}{|c|c|c|c|c|c|}
\hline \multirow[t]{2}{*}{ Respondent } & \multicolumn{2}{|c|}{ skills of sender of electronic message } & $\begin{array}{l}\text { skills of receiver of } \\
\text { electronic message }\end{array}$ & \multicolumn{2}{|c|}{ Skills of sender and receiver } \\
\hline & Respondent to husband & Respondent to child & $\begin{array}{l}\text { Respondent to } \\
\text { husband }\end{array}$ & Respondent to children & \\
\hline $\begin{array}{l}\text { Respondent } \\
\text { L }\end{array}$ & $\begin{array}{l}\text { In sending an electronic } \\
\text { message to her husband, } \\
\text { respondent L use concrete } \\
\text { and spontaneous words } \\
\text { detail, describe feeling. } \\
\text { Respondent present idea } \\
\text { politely, but sometimes } \\
\text { she's not especially when } \\
\text { she was on deadline }\end{array}$ & $\begin{array}{l}\text { In sending an electronic } \\
\text { message to her son, } \\
\text { respondent L use con- } \\
\text { crete words detail, she } \\
\text { thinks a lot before speak } \\
\text { and not describe nega- } \\
\text { tive feeling. Respondent } \\
\text { present idea very polite- } \\
\text { ly. }\end{array}$ & $\begin{array}{l}\text { Respondent L listens } \\
\text { actively when com- } \\
\text { municate with the } \\
\text { husband, sensitive, } \\
\text { and support and } \\
\text { praise. Her husband } \\
\text { does to. }\end{array}$ & $\begin{array}{l}\text { When communicate with } \\
\text { her son, she empathy to } \\
\text { her son feelings, do sup- } \\
\text { port, praise and comforting } \\
\text { his sons feeling. Her son } \\
\text { sometimes don't want to } \\
\text { listen actively and use eye } \\
\text { contact, and sometimes cry } \\
\text { when see her mother in } \\
\text { video call }\end{array}$ & $\begin{array}{l}\text { The dialog with her } \\
\text { husband takes place } \\
\text { equally, while the } \\
\text { mother was most the } \\
\text { sender when communi- } \\
\text { cate with her son }\end{array}$ \\
\hline $\begin{array}{l}\text { Respondent } \\
\text { W }\end{array}$ & $\begin{array}{l}\text { Respondent W use con- } \\
\text { crete words detail, de- } \\
\text { scribe feeling and present } \\
\text { idea politely by verbal and } \\
\text { non-verbally }\end{array}$ & - & $\begin{array}{l}\text { They are listen each } \\
\text { other, show caring } \\
\text { and sensitive feel- } \\
\text { ings, support and } \\
\text { praise each other }\end{array}$ & - & $\begin{array}{l}\text { The dialogue takes } \\
\text { place equally, and } \\
\text { Communication is done } \\
\text { continuously }\end{array}$ \\
\hline $\begin{array}{l}\text { Respondent } \\
\text { G }\end{array}$ & $\begin{array}{l}\text { Respondent G, use con- } \\
\text { crete but not detail words, } \\
\text { describe feeling, present }\end{array}$ & $\begin{array}{l}\text { Respondent G, use } \\
\text { concrete but not detail } \\
\text { words, describe feeling, }\end{array}$ & $\begin{array}{l}\text { Respondent G listen } \\
\text { word, support and } \\
\text { praise. Their use }\end{array}$ & $\begin{array}{l}\text { Respondent G listens be- } \\
\text { yond the word, and very } \\
\text { concern when communi- }\end{array}$ & $\begin{array}{l}\text { The dialog with her } \\
\text { husband takes place } \\
\text { more equally, while }\end{array}$ \\
\hline
\end{tabular}




\begin{tabular}{|c|c|c|c|c|c|}
\hline & $\begin{array}{l}\text { idea politely. So do the } \\
\text { husband }\end{array}$ & $\begin{array}{l}\text { present idea very polite- } \\
\text { ly when communicate } \\
\text { with her son }\end{array}$ & $\begin{array}{l}\text { verbal and nonver- } \\
\text { bal effectively }\end{array}$ & $\begin{array}{l}\text { cate with her } 2 \text { years old } \\
\text { son, always praise and } \\
\text { comforting his son. Their } \\
\text { use verbal and nonverbal } \\
\text { by video calling. }\end{array}$ & $\begin{array}{l}\text { the mother was most } \\
\text { active sender when } \\
\text { communicate with her } \\
\text { son }\end{array}$ \\
\hline Responded D & $\begin{array}{l}\text { Respondent D, use liter- } \\
\text { ally words, describe feel- } \\
\text { ing and present idea po- } \\
\text { litely when communicate } \\
\text { with her husband }\end{array}$ & $\begin{array}{l}\text { Respondent and the } \\
\text { children also express his } \\
\text { feeling literally by word } \\
\text { and icon or another } \\
\text { nonverbal message. } \\
\text { They build a dialogue } \\
\text { by group }\end{array}$ & $\begin{array}{l}\text { Respondent D listen } \\
\text { actively, when tex- } \\
\text { ting, they respond } \\
\text { the message. They } \\
\text { listen sensitive, and } \\
\text { support and praise. }\end{array}$ & $\begin{array}{l}\text { Respondent D always listen } \\
\text { sensitive her children feel- } \\
\text { ings, and support and praise } \\
\text { when they have a good } \\
\text { attitude. }\end{array}$ & $\begin{array}{l}\text { The dialog with her } \\
\text { husband and children } \\
\text { takes place equally }\end{array}$ \\
\hline
\end{tabular}

Based on table 1, respondent $\mathrm{L}$ have a good skills of sender when communicate with her husband but not very effective when communicate with her son, the skill of receiver were good when communicate with her son but not always great when communicate with her husband, dialogue not always equal when communicate with her son. Respondent W have a good skills of sender and receiver when communicate with her husband, the dialogue takes places equally. Respondent $\mathrm{G}$ have a good skills of sender when communicate with her husband but not very effective when communicate with her son because his son still 2 years old, the skill of receiver were good when communicate with her son and husband. Dialogue takes place equally. We have a good skills of sender and receiver when communicate with her husband and children, the dialogue also takes places equally. Respondent $\mathrm{L}$ and respondents D not really success when communicate with their young sons because the L son sometimes cry when communicate with his mom, and D son still 2 years old, so mother a lot of use nonverbal communication to communicate with her son.

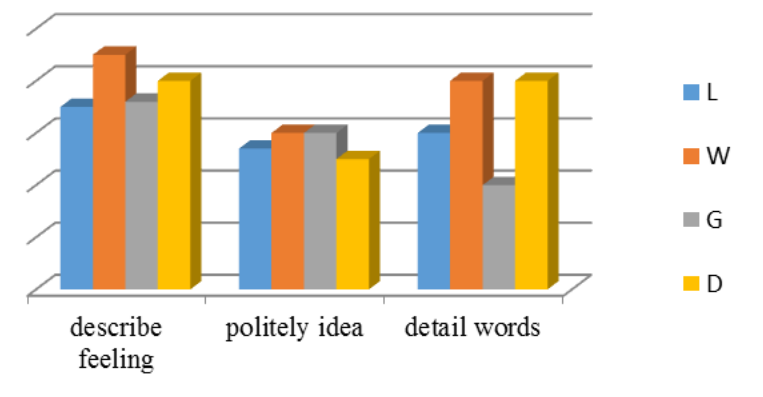

Fig. 3: Skill of sender of electronic message
Based on picture 3 had seen that the majority of respondent had a very good skills of sender in electronic message by expression and describe their feeling, had an enough skills of state idea politely. Respondent W and D had communicated with very detail words but Respondent $\mathrm{L}$ and $\mathrm{G}$ not really detail words.

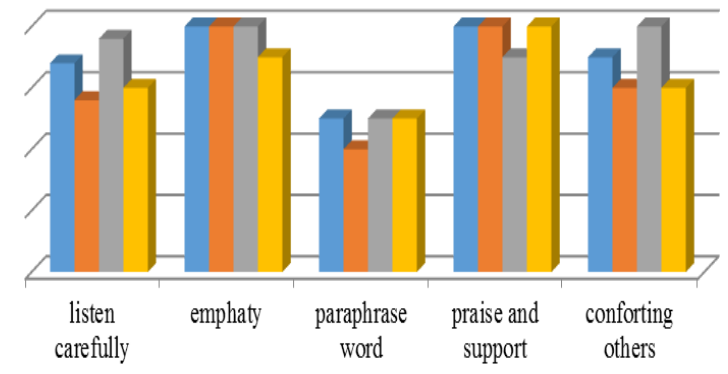

Fig. 4: Skill of receiver of electronic message

Based on picture 4, almost all respondent had a high skill of receiver, excluding in paraphrase word, because they usually have spontaneous word and not think a lot of time before communicate with the family.

\subsubsection{Perception and Communicating Role as Wife and/or Mother in Commuter Marriage}

The studies through depth interview with 4 [fours] respondent, found that perception and communicating role as wife and/or mother in commuter marriage describe on table below.

Table 2: Perception and Communicating role as a wife and /or as a mother

\begin{tabular}{|c|c|c|c|}
\hline Respondent & Frequency of communicate & The perception about commuter marriage & $\begin{array}{c}\text { Communicating Role of mother and/or } \\
\text { wife }\end{array}$ \\
\hline $\begin{array}{l}\text { Respondent } \\
\text { L }\end{array}$ & $\begin{array}{l}\text { Respondent communicate } \\
\text { everyday with her son and } \\
\text { husband, with her son, she } \\
\text { mostly communicate by video } \\
\text { calling. She communicates all } \\
\text { the time with her husband by } \\
\text { texting chat especially by } \\
\text { WhatsApp. }\end{array}$ & $\begin{array}{l}\text { Respondent L and her husband had legalitarian view and } \\
\text { support each other when they life a long distance. But } \\
\text { sometimes the surrounding environment looked negative- } \\
\text { ly they decision to commuter relation and leaving the } \\
\text { family temporary to go aboard. The negative perception } \\
\text { also. Respondent also posting the view of One of the } \\
\text { college friends in Facebook timeline who questioned the } \\
\text { respondent's decision to go overseas school. Sometimes } \\
\text { that perception Sometimes the perception has a little bit } \\
\text { affect her feeling, but family support makes it strong } \\
\text { againn }\end{array}$ & $\begin{array}{l}\text { Respondent L mainly coordinate the role } \\
\text { of parenting with his husband and com- } \\
\text { municate and discuss every day and al- } \\
\text { most all the time by chat message about } \\
\text { the child. She always doing video calling } \\
\text { with her son to share about a child's daily } \\
\text { activities, Although sometimes the child } \\
\text { does not always pay attentionn, because } \\
\text { he want her mother to go home. }\end{array}$ \\
\hline Respondents & $\begin{array}{l}\text { Respondent W communicate } \\
\text { with her husband continuously } \\
\text { almost every day by texting } \\
\text { chat and video call. }\end{array}$ & $\begin{array}{l}\text { Respondents husband is a French man who accustomed } \\
\text { to western culture and egalitarian views. So he always } \\
\text { support self-actualization of respondents and go overseas } \\
\text { to school. As well as the environment of the respondent } \\
\text { in his hometown and in the campus environment where } \\
\text { he attended to school. }\end{array}$ & $\begin{array}{l}\text { Communicate frequently with his hus- } \\
\text { band, show attention and care each other } \\
\text { as wife and husband by online. They are } \\
\text { also accustomed to giving gifts }\end{array}$ \\
\hline $\begin{array}{l}\text { Respondents } \\
\text { G }\end{array}$ & $\begin{array}{l}\text { Respondents communicate } \\
\text { with family every two days. } \\
\text { By texting message with hus- } \\
\text { band and by video call with } \\
\text { son and husband }\end{array}$ & $\begin{array}{l}\text { Husbands and parents of respondents support the decision } \\
\text { to study abroad even though there are some big families } \\
\text { and surroundings that have negative perceptions. But the } \\
\text { respondents remained strong and unaffected by the nega- } \\
\text { tive view. }\end{array}$ & $\begin{array}{l}\text { Respondent G, communicate as mother } \\
\text { and wife. She monitors the activity of her } \\
\text { children by video calling. Respondents } \\
\text { often Reading storybooks and storytelling } \\
\text { using toys via video calls with her } 2 \text { years } \\
\text { old son. She always coordinates the ac- } \\
\text { tivity of her son with husband and her } \\
\text { parent. }\end{array}$ \\
\hline $\begin{array}{l}\text { Respondent } \\
\text { D }\end{array}$ & $\begin{array}{l}\text { Respondents communicate } \\
\text { with husband and her children } \\
\text { always every time by texting }\end{array}$ & $\begin{array}{l}\text { Core family of respondents always supports respondents } \\
\text { to actualize themselves. So the negative perception of } \\
\text { society about mother who study abroad and live separate }\end{array}$ & $\begin{array}{l}\text { Respondent D has a group WhatsApp to } \\
\text { coordinate with their family as mother and } \\
\text { wife. The member of family always coor- }\end{array}$ \\
\hline
\end{tabular}


Based on Table 2, it can be seen that almost all of respondent communicate with her family almost every day. Even, Responden $\mathrm{L}$ and $\mathrm{G}$ communicate almost any time with their husband by social media texting message. All of the respondent had support from their nuclear family, and had a negative perception from their larger society. Respondents L and Respondent G coordinate the parental with the husband and other families they communicate and show attention with the husband literally and continuously. Respondent W show attention each other with her husband Respondent D, coordination and share their activity and feeling with the member of family by social media, she also coordinate her children by social media private message and group anytime.

\subsection{Findings}

The result of this studies found that all of the respondent use social media to communicate with their family. Social media could use as electronically Mediated Interpersonal Communication, which respondent communicate to related especially with her husband and her children. Social media is online type of electronic media, [3] stated that Electronically mediated interpersonal communication includes interactions both online and offline. Online types are by email, newsgroup, and chatroom. Offline types are by orally via cellular telephone.

The result of this studies found that respondent has enough of skill of sender are expression their feeling, discussed politely enough and use concrete and detail words as told by [3] that sender skills are use concrete word, provide detail, describe feeling, present idea politely. The Respondents also have good skills of receiver of online message which they are empathy to another feeling, give support and praise to husband and children, and comforting each other with husband and always use words to comforting their child. The respondents have high competencies excluding a competence on paraphrase idea because some of respondents speak and write spontaneously. That skills as told by [11] that receives skill are listen actively, sensitive of another feeling, paraphrase idea before respond, supportive, praise and comforting others. The capabilities of respondents as sender and receiver also could be choices for improving online communication skills as told by [14] that are, improving sender skill for electronic message by be succinct when necessary, write literally, stay polite, and take a deep breath. Improving receiving skills for electronic message by check in with sender, show empathy when possible, listen beyond the words.

The respondents could maintain dialogue with her husband and children equally and continuously. Except communication with the sons of respondent $\mathrm{L}$ and respondent $\mathrm{G}$, because their still young ages children, so the communication mostly done by mother as a sender. As told by [14] that improving sender and receiver skills for electronic messages by take responsibility for your own words, built your dialogue and recall the challenge of online communication. The dialectics through equal and continuous dialogue also built relationship satisfaction. [12] studies found indicate that dialectics do play a role in the relationship satisfaction, communication satisfaction, and feelings of understanding of long distance married couples. Furthermore, the feelings of understanding or misunderstanding scale performed well both as a predictor and outcome variable, indicating a potentially important communication-related variable at work in long distance marriages. Finally, sustenance strategies at work in long distance marriages are significantly related to dialectics and feelings of understanding or misunderstanding.

Respondent could kept maintaining the role of a mother and reduce the loneliness feeling and guilty feeling by video call and social media chatting. Respondent also keep support and stimulate each other. [5] stated that at least $80 \%$ in every age group regards online communication as a helpful way to stay in touch with family members. They belong to online communities that provide social stimulation, advice, and support. Respondent have a young age children especially respondents $\mathrm{G}$ who have 2-year-old chil- dren who still need childcare from their parent. Culture of eastern Indonesia in general, children mostly taken care by mother. With the condition of Mother studying abroad, then father role in child care is very big. A father actually has a big role in the formation of self-concept and child's personality. Cognitive development, social competence of early childhood is influenced by the attachment, emotional connection and availability of resources provided by the father[15]. Dad is the foundation of intellectual ability, problem-solving skills, and issues related to the child's cognitive problem [6].

Indonesian with the eastern culture and patriarchy, a wife usually stay at home and obey the husband's orders. So do not be surprised if people around the respondents have a poor perception of mothers who study abroad and leave the family for a while. But egalitarian views can generally accept the situation and assume that women have the right to actualize themselves. Respondents generally have no difficulty and don't have big guilty feeling because the nuclear family in general has egalitarian views and support them. When husband have egalitarian views, Husband will tolerate and not sue wife. So that, unequal role between husband and wife in parenting will not be a problem. This is very important to long distance relationship. [Sahlstein, 2006; Stafford, 2005 in [5] stated that one of problems, or tensions, are commonly experienced in long-distance relationships is unequal effort invested by the two partners; Not equally investment could built dejection to person whose assuming majority of work to keep relationship alive and may create guilty feeling to the person whose investing less. According to [9], couples with equally egalitarian gender role attitudes are the most psychologically prosperous couples, while the two have traditional psychological wellbeing among the other groups. Couples who do not share the affairs of the house in a balanced manner can cause stress or pressure on one side, especially in women who will reduce harmony in marriage life [10]. By video calling, respondent still could connect with the children and maintain eye contact to play a mothers role. Respondents G often reading storybooks and storytelling using toys via video calls with her 2 years old son. So the son still can feel closeness with his mother. Respondent D also could coordinate with her children by social media, to share activities and provide direction to her children. So the social media could be an effective family communication media. . Lestari revealed that one of the functions of the family is the socialization function to prepare the child to be a good member of society [7] . Mothers must communicate effectively in building relationships with children. Messages support from parents such as praise, acceptance, courage, and affectionate appeals are associated with high self-esteem in children and compliance with authority will be greater [4].

In relationship with spouse, respondent with commuter marriage ccouples. When they live in separatee residences, they communicate continuously and effectively, they support each other, praise, giving give and show feelings. Support, expression of feeling, giving a given is some of way to communicate love. Chapman in [5] has identified five distinct ways that we communicate love, which calls the five love languages: affirming words [Written or oral compliments, support, and expressions ], quality time, Gifts, service, and touch Long distance relationship sometimes has a relatively more stable relationship and they have good quality time when meet up and be together. In fact, there are some noteworthy advantages of long distance relationships. Blake, Reske \& Stafford, in [5] stated that because couples are not together continually, they tend to be more loving and passionate when they are together. Then, commitment, flexibility, and effective interpersonal communication could help the couples meet the challenges of keeping romance healthy and satisfying over the life of the relationship.

[12] studies found indicate that dialectics do play a role in the relationship satisfaction, communication satisfaction, and feelings of understanding of long distance married couples. Furthermore, the feelings of understanding or misunderstanding scale performed 
well both as a predictor and outcome variable, indicating a potentially important communication-related variable at work in long distance marriages. Finally, sustenance strategies at work in long distance marriages are significantly related to dialectics and feelings of understanding or misunderstanding.

\section{Conclusion}

a. The respondent used Social Media to Communicate with their family, especially by WhatsApp, line, Facebook and Skype.

$b$. The most of respondents has enough skills of both sender and receiver for electronic message.

c. The respondent could kept maintaining the role of a mother and reduce the loneliness feeling and also guilty feeling by video call and social media chatting. They also not very affected by negative perception of environment because of support from their nuclear family.

d. The contribution of this study was to give recommendation to some mother who's in commuter marriage to escalate the skills of family communication trough social media so they could still run the role of mother and wife as much as they could.

\section{Acknowledgement}

This research work is supported by BUDI DN LPDP 2016 [ 2016141100800]

\section{References}

[1] Nasrullah R. Media Sosial, Perspektif Komunikasi, Budaya dan Sosioteknologi. Bandung: Simbiosa Rekatama Media. 2015.

[2] Le Poire BA. Family communication: Nurturing and control in a changing world: Sage; 2006.

[3] Verderber K, Beebe SA, Verberber K. Inter act: Interpersonal Communication, concepts, skills and: Oxford; 2004.

[4] Trenholm S, Jensen A. Interpersonal communication: Oxford University Press New York; 2008.

[5] Wood JT. Interpersonal communication: Everyday encounters: Nelson Education; 2015.

[6] Abdullah SM. Studi Eksplorasi tentang Peran Ayah dalam Pengasuhan Anak Usia Dini. Jurnal SPIRITS. 2010;1[1].

[7] Lestari S. Psikologi keluarga: penanaman nilai dan penanganan konflik dalam keluarga: Sri Lestari; 2012.

[8] Bornstein MH. Handbook of parenting: volume 4 social conditions and applied parenting: Psychology Press; 2005.

[9] Lianawati E. Kesejahteraan psikologis istri ditinjau dari sikap peran gender pada pasutri muslim. Jurnal Ilmiah Psikologi. 2011;2[1].

[10] Claffey ST, \& Mickelson, K. D. . Division of Household Labor and Distress: The Role of Perceived Fairness for Employed Mothers. Sex Role. Proquest. 2009:819-31

[11] Bergen KM. WOMEN'S NARRATIVES ABOUT COMMUTER MARRIAGE: HOW WOMEN IN COMMUTER MARRIAGES ACCOUNT FOR AND COMMUNICATIVELY NEGOTIATE IDENTITIES WITH MEMBERS OF THEIR SOCIAL NETWORKS: University of Nebraska; 2006.

[12] Scott AT. Communication characterizing successful long distance marriages: St. Mary's University; 2002.

[13] Vangelisti AL. The Routledge handbook of family communication Routledge; 2012.

[14] West R, Turner LH. Understanding interpersonal communication Making choices in changing times: Cengage Learning; 2010.

[15] Brown BV. The single-father family: Demographic, economic, and public transfer use characteristics. Marriage \& Family Review. 2000;29[2-3]:203-20 